\title{
Nucleotide-binding oligomerization domain containing I (NODI) haplotypes and single nucleotide polymorphisms modify susceptibility to inflammatory bowel diseases in a New Zealand caucasian population: a case-control study
}

\author{
Claudia Huebner ${ }^{1,7}$, Lynnette R Ferguson*1,7, Dug Yeo Han 1,7,
} Martin Philpott ${ }^{1,7}$, Murray L Barclay ${ }^{2,3}$, Richard B Gearry ${ }^{2,3}$, Alan McCulloch ${ }^{4,7}$, Pieter S Demmers ${ }^{5,7}$ and Brian L Browning ${ }^{6}$

\begin{abstract}
Address: ${ }^{1}$ Discipline of Nutrition, The University of Auckland, Private Bag 92019, Auckland 1023, New Zealand, ${ }^{2}$ Department of Gastroenterology Christchurch Hospital, Christchurch 8011, New Zealand, ${ }^{3}$ Department of Medicine, University of Otago, Christchurch, New Zealand, ${ }^{4}$ Information Services, Plant and Food Research, Mosgiel 9053, New Zealand, ${ }^{5}$ Information Services, AgResearch Limited, Mosgiel 9053, New Zealand, ${ }^{6}$ Department of Statistics, The University of Auckland, Private Bag 92019, Auckland 1023, New Zealand and ${ }^{7}$ Nutrigenomics, Web, New Zealand

Email: Claudia Huebner - c.huebner@auckland.ac.nz; Lynnette R Ferguson* - l.ferguson@auckland.ac.nz;

Dug Yeo Han -dy.han@auckland.ac.nz; Martin Philpott - m.philpott@auckland.ac.nz; Murray L Barclay - Murray.Barclay@cdhb.govt.nz; Richard B Gearry - richard.gearry@cdhb.govt.nz; Alan McCulloch - alan.mcculloch@agresearch.co.nz;

Pieter S Demmers - DemmersP@crop.cri.nz; Brian L Browning - b.browning@auckland.ac.nz

* Corresponding author
\end{abstract}

\section{Published: 27 March 2009}

BMC Research Notes 2009, 2:52 doi:10.1/86/1756-0500-2-52
Received: 20 August 2008

Accepted: 27 March 2009

This article is available from: http://www.biomedcentral.com/I756-0500/2/52

(c) 2009 Ferguson et al; licensee BioMed Central Ltd.

This is an Open Access article distributed under the terms of the Creative Commons Attribution License (http://creativecommons.org/licenses/by/2.0), which permits unrestricted use, distribution, and reproduction in any medium, provided the original work is properly cited.

\begin{abstract}
Background: The nucleotide-binding oligomerization domain containing I (NODI) gene encodes a pattern recognition receptor that senses pathogens, leading to downstream responses characteristic of innate immunity. We investigated the role of NOD/ single nucleotide polymorphisms (SNPs) on IBD risk in a New Zealand Caucasian population, and studied Nodl expression in response to bacterial invasion in the Caco2 cell line.

Findings: DNA samples from 388 Crohn's disease (CD), 405 ulcerative colitis (UC), 27 indeterminate colitis patients and $20 \mathrm{I}$ randomly selected controls, from Canterbury, New Zealand were screened for 3 common SNPs in NODI, using the MassARRAY ${ }^{\circledR}$ iPLEX Gold assay. Transcriptional activation of the protein produced by NODI (NodI) was studied after infection of Caco2 cells with Escherichia coli LF82. Carrying the rs $2075818 \mathrm{G}$ allele decreased the risk of $\mathrm{CD}(\mathrm{OR}=0.66,95 \% \mathrm{Cl}=0.50-0.88, \mathrm{p}<0.002)$ but not UC. There was an increased frequency of the three SNP (rs20758I8, rs2075822, rs2907748) haplotype, CTG $(p=0.004)$ and a decreased frequency of the GTG haplotype $(p=0.02)$.in CD. The rs2075822 CT or TT genotypes were at an increased frequency (genotype $p$ value $=0.02$ ), while the rs2907748 AA or AG genotypes showed decreased frequencies in UC $(p=0.04)$, but not in CD. Functional assays showed that Nodl is produced 6 hours after bacterial invasion of the Caco2 cell line.

Conclusion: The NODI gene is important in signalling invasion of colonic cells by pathogenic bacteria, indicative of its' key role in innate immunity. Carrying specific SNPs in this gene significantly modifies the risk of $C D$ and/or UC in a New Zealand Caucasian population.
\end{abstract}




\section{Background}

Pathogens are sensed by pattern recognition receptors (PRRs), including cytosolic nucleotide oligomerisation domain (Nod) proteins, resulting in downstream responses involving the activation of transcription factors and the induction of apoptosis genes. Intestinal epithelial cells are among several cell types that express such proteins, including Nod 1 and Nod 2 [1].

Since initial publications claiming that single nucleotide polymorphisms (SNPs) in NOD2 provide a major risk factor for CD $[2,3]$, there have been many reports of other susceptibility alleles [4]. Nod2 recognizes a range of bacteria through a cell wall peptidoglycan. However, the related Nod 1 may be even more important, since it senses a wider range of pathogens. In epithelial cells, Nod1 appears to be indispensable for sensing of intracellular gram-negative bacteria [1].

The NOD1 gene (MIM\# 605980) is located on chromosome 7p14.3. An initial study reported no relationship between SNPs in NOD1 and risk of IBD in European patients [5]. However, McGovern and co-workers [6] pointed out that the SNP tested was a rare variant, and that the risk of complex diseases is associated with regulatory mutations that occur commonly in a population. These authors reported an association between a complex insertion/deletion polymorphism in NOD1 and susceptibility to $\mathrm{CD}$ in a European population. However, although Canto et al, [7] found similar results in their Spanish subjects, several other studies have failed to replicate this finding in other European populations [8-10]. Although the main focus of the original McGovern et al., [6] paper was on the complex deletion, associations were also observed between IBD and several other SNPs, including NOD1 c. 156C>G $(\mathrm{P}<0.02)$ and g27606C $>$ T, $(\mathrm{P}$ $<0.05)$. They also reported an association with haplotypes containing g.45343G $>$ A.

SNPs in the genes for three different pattern recognition receptors (NOD2, DLG5 and TLR4) have been previously associated with CD in the New Zealand population [1113]. Here we consider the implications of three different NOD1 SNPs for their effects on IBD susceptibility in a Caucasian population from the Canterbury region of $\mathrm{New}$
Zealand. We also consider the functional role of Nod1 in relation to invasion of the gastrointestinal colon cell line, Caco 2 by the CD-associated bacterium, Escherichia coli LF82 [14].

\section{Results \\ Case control study}

Clinical and demographic characteristics of the IBD cohort are given in Table 1. The SNPs selected for analysis were: c.156C>G (rs2075818; synonymous SNP), g.27606T>C (rs2075822; intronic SNP), and g.45343G>A (rs2907748; intronic SNP) (Table 2; [6]).

Carrying the NOD1 c. $156 \mathrm{C}>\mathrm{G}$ variant led to statistically significant changes in CD or overall IBD risk, but not UC risk. Table 3 shows a significant difference in the major (C) allele frequencies between CD patients $(81.1 \%)$ and controls $(73.9 \%)(\mathrm{p}=0.004)$, such that those individuals carrying the $\mathrm{C}$ allele have an increased probability of developing $\mathrm{CD}$ in this population $(\mathrm{OR}=1.51,95 \% \mathrm{CI}=$ 1.13-2.02, $\mathrm{p}=0.004)$. CG heterozygotes have a reduced risk of $\mathrm{CD}(\mathrm{OR}=0.53,95 \% \mathrm{CI}=0.37-0.75, \mathrm{p}=0.002)$, and of developing IBD as compared with CC homozygotes $(\mathrm{OR}=0.64,95 \% \mathrm{CI}=0.46-0.88, \mathrm{p}=0.01)$.

Carrying the NOD1 g.27606C>T variant led to statistically significant changes in the probability of developing UC, but not CD (Table 3 ). The CT heterozygote had a 2.65fold $(\mathrm{OR}=2.65,95 \% \mathrm{CI}=1.29-5.41)$ greater risk, while TT homozygotes had a 2.45 -fold $(\mathrm{OR}=2.45,95 \% \mathrm{CI}=$ 1.23-4.85) greater risk of developing the disease, as compared with the risk for $\mathrm{CC}$ homozygotes $(\mathrm{p}=0.02)$. For g.45343G>A SNP, it is the major allele that carries the increased risk. AG heterozygotes $(\mathrm{OR}=2.32,95 \% \mathrm{CI}=$ $1.18-4.53)$ and GG homozygotes ( OR $=2.19,95 \% \mathrm{CI}=$ 1.14-4.22) have an increased risk of developing the disease, as compared with AA homozygotes $(p=0.04)$. There was no significant difference in the allele frequencies between control subjects and CD, UC, or IBD patients (Table 3).

We also report results from extensive subgroup analysis using sets of cases defined by gender, age of diagnosis, disease location, disease behaviour, need for surgery, smoking history, use of immunomodulators, and presence of

Table I: NODI polymorphisms tested in the Canterbury population

\begin{tabular}{|c|c|c|c|c|}
\hline rs Number & Location & Nucleotide change ${ }^{a}$ & Protein domain & Frequencyb \\
\hline \multirow[t]{2}{*}{ rs20758I8 } & Exon 4 & c. $156 C>G$ & CARD & $0.869(n=214)$ \\
\hline & & g. $21984 C>G$ & & \\
\hline rs 2075822 & Intron 6 & g. $27606 \mathrm{~T}>\mathrm{C}$ & & $0.706(n=92)$ \\
\hline rs2907748 & Intron II & $g .45343 G>A$ & & $0.735(n=200)$ \\
\hline
\end{tabular}

a. The position is numbered from the first nucleotide of exon I. The sequence is obtained from dbSNP http://www.ncbi.nlm.nih.gov/SNP/.

b. Frequency of major SNPs in a European population as a mean for European samples submitted to dbSNP http://www.ncbi.nlm.nih.gov/SNP/. 
Table 2: Summary of clinical and demographic data for the set of Caucasian IBD patients

\begin{tabular}{|c|c|c|c|}
\hline & $\begin{array}{c}C D \\
\mathrm{n}(\%)\end{array}$ & $\begin{array}{c}\mathrm{UC} \\
\mathrm{n}(\%)\end{array}$ & $\begin{array}{c}\text { IC } \\
\mathrm{n}(\%)\end{array}$ \\
\hline \multicolumn{4}{|l|}{ Gender } \\
\hline Female & $249(64.2)$ & $214(52.8)$ & $15(55.6)$ \\
\hline Male & $139(35.8)$ & $191(47.2)$ & $12(44.4)$ \\
\hline \multicolumn{4}{|l|}{ Age at first diagnosis } \\
\hline Below 17 & $39(10.0)$ & $26(6.4)$ & 0 \\
\hline Between 17 and 40 & $199(5 \mid .3)$ & $184(45.4)$ & $15(55.6)$ \\
\hline Above 40 & $150(38.7)$ & $195(48.2)$ & $12(44.4)$ \\
\hline \multicolumn{4}{|l|}{ CD location } \\
\hline lleal & $125(32.2)$ & & \\
\hline Colonic & $169(43.6)$ & & \\
\hline Ileocolonic & $90(23.2)$ & & \\
\hline Upper GI & $4(1.0)$ & & \\
\hline \multicolumn{4}{|l|}{ UC location } \\
\hline Proctitis & & 140 (34.6) & $3(I I . I)$ \\
\hline Left colon & & $107(26.4)$ & $5(18.5)$ \\
\hline Pancolitis & & $154(38.0)$ & $19(70.4)$ \\
\hline Unknown & & $4(1.0)$ & 0 \\
\hline \multicolumn{4}{|l|}{ Behaviour } \\
\hline Non-stricturing, non-penetrating perianal disease & $47(21.5)$ & & \\
\hline Stricturing perianal disease & $46(38.0)$ & & \\
\hline Penetrating perianal disease & $17(35.4)$ & & \\
\hline Any relative with IBD: Yes $(n=143)$ & $74(19.1)$ & $65(16.1)$ & $5(18.5)$ \\
\hline Bowel resection: Yes $(n=2 \mid 4)$ & $142(36.6)$ & $70(17.3)$ & $2(7.4)$ \\
\hline Smoker at diagnosis: Yes $(n=147)$ & $97(25.7)$ & $49(12.3)$ & $2(7.7)$ \\
\hline Ever used immunomodulators: Yes $(n=296)$ & $203(52.3)$ & $86(21.2)$ & $8(29.6)$ \\
\hline Extraintestinal manifestations: Yes $(n=142)$ & $75(19.3)$ & $64(15.8)$ & $3(11.1)$ \\
\hline
\end{tabular}

family history of IBD (Table 4). While several of these categories showed substantially increased risks associated with different SNPs, none explained an undue proportion of the CD cases.

Table 5 summarises haplotype analysis. A positive hapscore implies that the haplotype occurs more frequently in the CD or UC case group. A global p-value tests the overall association between haplotypes and the response.

These haplotypes differed significantly between CD patients and control subjects $\left(\chi^{2}=9.55, \mathrm{df}=3, \mathrm{p}=0.02\right)$ (Table 5). Haplotype CTG frequencies in cases was $55.8 \%$ and in controls $46.9 \%(\mathrm{p}=0.004)$. The frequencies of haplotype GTG were $16.0 \%$ and $21.7 \%$ for CD case and control subjects respectively $(\mathrm{p}=0.02)$. Haplotypes CCG, CTA, GCA, and GCG were the most uncommon in CD cases and control subjects, and occurred at equal frequencies in the two groups ( $p>0.05)$. There were no significant associations between these haplotypes for UC cases as compared with control subjects $\left(\chi^{2}=2.30, \mathrm{df}=3, \mathrm{p}=\right.$
0.51). Haplotype CTG was the most common in UC cases but occurred at equal frequencies between UC case and control subjects $(\mathrm{p}>0.05)$.

\section{Crohn's disease-associated Escherichia coli LF82 leads to the transcriptional activation of NodI}

The gastrointestinal colon cell line $\mathrm{Caco} 2$ was infected with LF82 for $6 \mathrm{~h}$ and $9 \mathrm{~h}$, respectively. Infection with this bacterial strain leads to increased Nod1 m RNA levels for the $6 \mathrm{~h}$ time point ( 4.3 fold increase as measured using quantitative real time PCR), whereas after $9 \mathrm{~h}$ infection the Nod1 expression levels were similar to the uninfected state (Figure 1). As Nod1 signalling leads to the activation of NF- $\kappa \mathrm{B}$, we also tested the mRNA expression for this gene. Infection of Caco2 cells with the E. coli strain LF82 results in an upregulation for NF- $\kappa$ B for $6 \mathrm{~h}$ (3.2 fold increase) and $9 \mathrm{~h}$ (2.4 fold increase).

\section{Discussion}

The present study adds to a growing database supporting a role for pattern recognition receptors ininflammatory 
Table 3: Genotype and allele counts for NODI/CARD4 variants in New Zealand IBD patients and in New Zealand Caucasians

\begin{tabular}{|c|c|c|c|c|c|c|c|}
\hline \multirow[t]{2}{*}{ SNP } & \multirow{2}{*}{$\begin{array}{c}\text { Controls } \\
\mathrm{n}(\%)\end{array}$} & \multicolumn{2}{|c|}{$C D$} & \multicolumn{2}{|c|}{ UC } & \multicolumn{2}{|c|}{$C D+U C$} \\
\hline & & n (\%) & $\begin{array}{c}\text { OR } \\
(95 \% \mathrm{Cl})\end{array}$ & n (\%) & $\begin{array}{c}\text { OR } \\
(95 \% \mathrm{Cl})\end{array}$ & n (\%) & $\begin{array}{c}\text { OR } \\
(95 \% \mathrm{Cl})\end{array}$ \\
\hline \multicolumn{8}{|l|}{ NODI rs20758I8 } \\
\hline $\mathrm{CC}$ & $105(52.2)$ & $255(66.7)$ & $\begin{array}{c}1.29 \\
(0.56-2.98)\end{array}$ & $226(56.5)$ & $\begin{array}{c}0.61 \\
(0.28-\mid .3 I)\end{array}$ & $48 \mid(6 \mid .4)$ & $\begin{array}{c}0.84 \\
(0.40-1.77)\end{array}$ \\
\hline CG & $87(43.3)$ & III (29.0) & $\begin{array}{c}0.68 \\
(0.29-1.59)\end{array}$ & $142(35.5)$ & $\begin{array}{c}0.46 \\
(0.21-1.01)\end{array}$ & $253(32.3)$ & $\begin{array}{c}0.53 \\
(0.25-1.13)\end{array}$ \\
\hline GG & $\begin{array}{c}9 \\
(4.5)\end{array}$ & $17(4.4)$ & 1.00 & $32(8.0)$ & 1.00 & $49(6.3)$ & 1.00 \\
\hline Genotype p-value & & \multicolumn{2}{|c|}{0.002} & \multicolumn{2}{|c|}{0.08} & \multicolumn{2}{|c|}{0.01} \\
\hline HWE p-value & 0.10 & \multicolumn{2}{|c|}{0.28} & \multicolumn{2}{|c|}{0.15} & \multicolumn{2}{|c|}{0.05} \\
\hline G & $105(26.1)$ & \multicolumn{2}{|c|}{145 (I8.9) } & \multicolumn{2}{|c|}{$206(25.8)$} & \multicolumn{2}{|c|}{$351(22.4)$} \\
\hline $\mathrm{C}$ & 297 (73.9) & \multicolumn{2}{|c|}{$621(81.1)$} & \multicolumn{2}{|c|}{$594(74.3)$} & \multicolumn{2}{|c|}{$1215(77.6)$} \\
\hline OR $(95 \% \mathrm{Cl})$ & & \multicolumn{2}{|c|}{$0.66(0.49-0.89)$} & \multicolumn{2}{|c|}{$0.98(0.74-1.30)$} & \multicolumn{2}{|c|}{$0.82(0.63-1.06)$} \\
\hline Allelic $p$-value & & \multicolumn{2}{|c|}{0.004} & \multicolumn{2}{|c|}{0.89} & \multicolumn{2}{|c|}{0.12} \\
\hline \multicolumn{8}{|l|}{ NODI rs2075822 } \\
\hline $\mathrm{CC}$ & $20(10.0)$ & $\begin{array}{c}28 \\
(7.3)\end{array}$ & 1.00 & $\begin{array}{c}17 \\
(4.2)\end{array}$ & 1.00 & $\begin{array}{c}45 \\
(5.7)\end{array}$ & 1.00 \\
\hline $\mathrm{CT}$ & $60(30.0)$ & $122(31.9)$ & $\begin{array}{c}1.45 \\
(0.76-2.79)\end{array}$ & $135(33.6)$ & $\begin{array}{c}2.65 \\
(1.29-5.4 I)\end{array}$ & $257(32.8)$ & $\begin{array}{c}1.90 \\
(1.05-3.46)\end{array}$ \\
\hline $\mathrm{TT}$ & $120(60.0)$ & $232(60.7)$ & $\begin{array}{c}1.38 \\
(0.75-2.55)\end{array}$ & $250(62.2)$ & $\begin{array}{c}2.45 \\
(1.23-4.85)\end{array}$ & $482(61.5)$ & $\begin{array}{c}1.79 \\
(1.02-3.14)\end{array}$ \\
\hline Genotype p-value & & \multicolumn{2}{|c|}{0.52} & \multicolumn{2}{|c|}{0.02} & \multicolumn{2}{|c|}{0.09} \\
\hline HWE p-value & 0.007 & \multicolumn{2}{|c|}{0.04} & & & & \\
\hline $\mathrm{C}$ & $100(25.0)$ & & 3.3) & & I.0) & & $2.1)$ \\
\hline $\mathrm{T}$ & $300(75.0)$ & & 6.7) & & $9.0)$ & 122 & 7.9) \\
\hline OR $(95 \% \mathrm{Cl})$ & & 0.91 & $-1.21)$ & 0.80( & $-1.06)$ & 0.85( & $-1.10)$ \\
\hline Allelic p-value & & & & & & & \\
\hline NODI rs2907748 & & & & & & & \\
\hline AA & $21(10.3)$ & $\begin{array}{c}31 \\
(8.2)\end{array}$ & 1.00 & $\begin{array}{c}20 \\
(5.0)\end{array}$ & 1.00 & $\begin{array}{c}51 \\
(6.6)\end{array}$ & 1.00 \\
\hline AG & $73(36.7)$ & $129(34.3)$ & $\begin{array}{c}1.20 \\
(0.64-2.23)\end{array}$ & $161(40.3)$ & $\begin{array}{c}2.32 \\
(1.18-4.53)\end{array}$ & $290(37.4)$ & $\begin{array}{c}1.64 \\
(0.93-2.89)\end{array}$ \\
\hline GG & $105(52.8)$ & $216(57.4)$ & $\begin{array}{c}1.39 \\
(0.76-2.54)\end{array}$ & $219(54.7)$ & $\begin{array}{c}2.19 \\
(1.14-4.22)\end{array}$ & $435(56.1)$ & $\begin{array}{c}1.7 \mid \\
(0.98-2.96)\end{array}$ \\
\hline Genotype p-value & & & & & & & \\
\hline HWE p-value & 0.12 & & & & & & \\
\hline$A$ & 115 (28.9) & & 5.4) & & 5.1) & & 5.3) \\
\hline G & $283(71.1)$ & & 4.6) & & $4.9)$ & 116 & $4.7)$ \\
\hline OR $(95 \% \mathrm{Cl})$ & & 0.84 & $1-1.10)$ & 0.83( & $-1.08)$ & 0.83( & $-1.06)$ \\
\hline Allelic $p$-value & & & & & & & \\
\hline
\end{tabular}


Table 4: Allelic odds ratios and $95 \%$ confidence intervals for comparison of NODI/CARD4 variants with IBD status in New Zealand IBD patients and Caucasians

\begin{tabular}{|c|c|c|c|c|c|c|}
\hline & \multicolumn{2}{|c|}{$\begin{array}{l}\text { Allelic odds ratios and } 95 \% \text { confidence } \\
\text { intervals for comparison of NODI } \\
\text { rs } 2075818\end{array}$} & \multicolumn{2}{|c|}{$\begin{array}{l}\text { Allelic odds ratios and } 95 \% \text { confidence } \\
\text { intervals for comparison of NOD I } \\
\text { rs } 2075822\end{array}$} & \multicolumn{2}{|c|}{$\begin{array}{c}\text { Allelic odds ratios and } 95 \% \text { confidence } \\
\text { intervals for comparison of NODI } \\
\text { rs } 2907748\end{array}$} \\
\hline & $\begin{array}{c}C D \\
\text { OR }(95 \% \mathrm{Cl})\end{array}$ & $\begin{array}{c}\text { UC } \\
\text { OR }(95 \% \mathrm{Cl})\end{array}$ & $\begin{array}{c}C D \\
\text { OR }(95 \% \mathrm{Cl})\end{array}$ & $\begin{array}{c}\text { UC } \\
\text { OR }(95 \% \mathrm{Cl})\end{array}$ & $\begin{array}{c}C D \\
\text { OR }(95 \% \mathrm{Cl})\end{array}$ & $\begin{array}{c}\text { UC } \\
\text { OR }(95 \% \mathrm{Cl})\end{array}$ \\
\hline Female & $0.66(0.46-0.96)$ & $0.94(0.65-1.36)$ & $1.14(0.79-1.64)$ & $1.18(0.8|-| .7 \mid)$ & $0.94(0.66-1.34)$ & $0.87(0.60-1.25)$ \\
\hline Male & $0.66(0.42-1.04)$ & $1.02(0.68-1.54)$ & $1.03(0.66-1.61)$ & $1.33(0.86-2.05)$ & $0.71(0.46-1.09)$ & $0.76(0.51-1.13)$ \\
\hline \multicolumn{7}{|l|}{$\begin{array}{l}\text { Age at first } \\
\text { diagnosis }\end{array}$} \\
\hline $0-16$ years & $0.62(0.33-1.15)$ & $0.94(0.48-1.83)$ & $0.75(0.44-1.28)$ & I.II (0.56-2.20) & I.II (0.65-1.90) & $1.20(0.65-2.23)$ \\
\hline $17-40$ years & $0.67(0.48-0.94)$ & $0.91(0.66-1.26)$ & $1.03(0.75-1.42)$ & $1.17(0.84-1.64)$ & $0.88(0.64-1.20)$ & $0.83(0.60-1.14)$ \\
\hline$>40$ years & $0.66(0.46-0.95)$ & $1.06(0.77-1.45)$ & $1.36(0.94-1.96)$ & $1.36(0.97-1.91)$ & $0.72(0.5 \mathrm{I}-1.02)$ & $0.78(0.57-1.07)$ \\
\hline \multicolumn{7}{|l|}{ CD location } \\
\hline Ileal & $0.82(0.56-1.19)$ & & $1.15(0.79-1.67)$ & & $0.71(0.49-1.03)$ & \\
\hline Colonic & $0.59(0.4 I-0.85)$ & & $1.22(0.86-1.72)$ & & $0.80(0.57-1.11)$ & \\
\hline Ileocolonic & $0.60(0.38-0.94)$ & & $0.89(0.60-1.33)$ & & $1.03(0.69-1.53)$ & \\
\hline \multicolumn{7}{|l|}{ UC location } \\
\hline Proctitis & & $0.94(0.67-1.32)$ & & $1.05(0.74-1.49)$ & & I.04 (0.75-I.44) \\
\hline Left colon & & $1.14(0.79-1.65)$ & & $1.43(0.95-2.16)$ & & $0.85(0.58-1.24)$ \\
\hline Pancolitis & & $0.92(0.65-1.31)$ & & $1.40(0.96-2.03)$ & & $0.58(0.40-0.84)$ \\
\hline \multicolumn{7}{|l|}{$C D$ Behavior } \\
\hline Inflammatory & $0.59(0.42-0.82)$ & & $1.10(0.80-1.5 \mathrm{I})$ & & $0.87(0.64-1.18)$ & \\
\hline Stricturing & $0.67(0.45-0.99)$ & & $1.23(0.84-1.81)$ & & $0.67(0.46-0.98)$ & \\
\hline Penetrating & $1.00(0.60-1.66)$ & & $0.85(0.52-1.40)$ & & $1.15(0.7 I-1.87)$ & \\
\hline Ileal/Stricturing & $0.71(0.45-1.13)$ & & $1.44(0.89-2.32)$ & & $0.48(0.29-(0.79)$ & \\
\hline $\begin{array}{r}\text { Colonic/ } \\
\text { Inflammatory }\end{array}$ & $0.61(0.42-0.89)$ & & $1.20(0.84-1.72)$ & & $0.82(0.58-1.16)$ & \\
\hline $\begin{array}{l}\text { Any relative with } \\
\text { IBD }\end{array}$ & $0.43(0.25-0.73)$ & $0.72(0.44-1.17)$ & $1.06(0.68-1.66)$ & $1.37(0.84-2.24)$ & $0.79(0.5 \mathrm{I}-1.22)$ & $0.57(0.35-0.93)$ \\
\hline Bowel resection & $0.75(0.52-1.08)$ & $0.91(0.58-1.43)$ & $1.10(0.77-1.58)$ & $0.88(0.57-1.36)$ & $0.72(0.50-1.03)$ & $1.28(0.85-1.93)$ \\
\hline $\begin{array}{l}\text { Smoker at } \\
\text { diagnosis }\end{array}$ & $0.84(0.56-1.26)$ & $1.16(0.71-1.90)$ & $1.40(0.92-2.14)$ & $1.09(0.65-1.83)$ & $0.69(0.46-1.03)$ & $0.75(0.45-1.26)$ \\
\hline $\begin{array}{l}\text { Ever used } \\
\text { immunomodulator } \\
\text { s }\end{array}$ & $0.70(0.50-0.98)$ & $0.90(0.59-1.36)$ & $1.18(0.85-1.64)$ & $1.10(0.72-1.67)$ & $0.81(0.59-1.11)$ & $0.94(0.63-1.40)$ \\
\hline Any EIMs & $0.60(0.37-0.97)$ & $0.77(0.48-1.24)$ & $1.08(0.69-1.68)$ & $1.25(0.77-2.02)$ & $0.93(0.61-1.42)$ & $0.80(0.5 \mathrm{I}-1.27)$ \\
\hline
\end{tabular}

bowel diseases [4]. Previous data associating NOD1 polymorphisms with IBD risk showed variable results. Zouali, et al., [5], with European subjects, and Ozen et al., [15] with Turkish patients, concluded that NOD1 was not involved in IBD. However, subject numbers in both studies were small. Molnar et al., [16] reported that the E266K (c.796G>A) NOD1 polymorphism was associated with disease susceptibility but not with disease phenotype or NOD2 or TLR4 polymorphisms in Hungarian patients with CD.

Following the very strongly positive associations reported by McGovern et al., [6], most of the more recent publications have focussed on the complex $\left(\mathrm{ND}(1)+32656^{*}\right)$
NOD1 deletion mutation. Canto et al, [7] reported that the distribution of the NOD1 polymorphism in patients was different from controls, and not altered by the existence of NOD2 mutations in their Spanish population. However, Van Limbergen et al, $[10,17]$ showed no statistically significant differences in frequency of this variant between cases and controls in large Scottish or Swedish populations. Similar results were reported by Franke et al., [8] (German subjects) and Tremelling et al., [9] (East Anglian subjects).

We are not certain of the functionality of the SNPs in the present study. We note that the insertion-deletion polymorphism $(\mathrm{ND}(1)+32656)$ that has given such variable 
Table 5: Haplotype analysis of three-SNP NODI haplotype in IBD patients and Caucasians in a New Zealand population.

\begin{tabular}{|c|c|c|c|c|c|c|}
\hline & Haplotype & Case subject frequency (\%) & Control subject frequency (\%) & $\mathrm{p}$-value & OR $(95 \% \mathrm{Cl})$ & Global score statistics \\
\hline \multirow[t]{6}{*}{$C D$} & Three SNPs NOD I gregion & & & & & \\
\hline & $\begin{array}{l}\text { (rs2075818, rs2075822, } \\
\text { rs2907748) }\end{array}$ & & & & & \\
\hline & CCA & 20.6 & 22.2 & 0.53 & $0.90(0.67-1.21)$ & $\chi^{2}=9.55$ \\
\hline & CTG & 55.8 & 46.9 & 0.004 & $1.44(1.12-1.85)$ & $\mathrm{df}=3$ \\
\hline & GTA & 3.3 & 4.2 & 0.25 & $0.77(0.4 I-1.45)$ & $p=0.02$ \\
\hline & GTG & 16.0 & 21.7 & 0.02 & $0.68(0.50-0.92)$ & \\
\hline \multirow[t]{6}{*}{ UC } & Three SNPs NOD I gregion & & & & & \\
\hline & $\begin{array}{l}\text { (rs20758I8, rs2075822, } \\
\text { rs2907748) }\end{array}$ & & & & & \\
\hline & $\mathrm{CCA}$ & 19.5 & 22.2 & 0.23 & $0.83(0.62-1.11)$ & $\chi^{2}=2.30$ \\
\hline & CTG & 51.9 & 46.9 & 0.14 & $1.19(0.93-1.52)$ & $\mathrm{df}=3$ \\
\hline & GTA & 3.8 & 4.2 & 0.79 & $0.89(0.48-1.63)$ & $p=0.51$ \\
\hline & GTG & 21.5 & 21.7 & 0.95 & $0.97(0.72-1.30)$ & \\
\hline
\end{tabular}

results in IBD population studies accounted for approximately $7 \%$ of the variation in IgE in two panels of families $(\mathrm{P}<0.0005$ in each $)[18]$. That is, there is in vivo evidence for functionality. According to our data the infection of Caco2 cells with the adherent-invasive Escherichia coli (AIEC) strain LF82 leads to the transcriptional activation of Nod1. AIEC strains have been specifically associated with CD ileal mucosa with a prevalence of 36.4\% [19].

Taken together, these data may suggest that NOD1 plays a variable role in different populations that could depend upon environmental and dietary factors. The gene may be especially important in Caucasian groups within New Zealand

\section{Methods}

\section{Participants and genotyping}

Cases for this study were provided through the Canterbury Inflammatory Bowel Disease Project, and controls randomly selected from a population-based cohort, both of which are described more fully elsewhere $[20,21]$. Both $\mathrm{CD}$ and UC were defined using standard diagnostic criteria, and cases phenotyped according to the Montreal Classification systems [22].

This study had ethical approval from the Canterbury Ethics Committee and the Southern Regional Health Authority's Ethics Committee in Canterbury, New Zealand, and all participants gave their written informed consent.

Genotyping was performed using the Sequenom MassArray ${ }^{\circledast}$ platform (Sequenom, San Diego, CA, USA) [23] using a chip-based matrix-assisted laser desorption ionisationtime-of-flight (MALDI-TOF) mass spectrometer [24], as previously described $[12,13]$. Multiplex SNP assays were designed using SpectroDesigner software and real-
SNP.com online tools (Sequenom, San Diego, CA, USA). Primers, sequences and assay conditions are shown in Table 6.

To estimate genotype accuracy, approximately $12 \%$ of the samples were genotyped in duplicate or triplicate. We estimated the error rate to be $<1 \%$.

\section{Bacterial strain and culture conditions for functional assays}

E. coli strain LF82, isolated from a chronic ileal lesion of a French patient with CD, was a kind gift of A. DarfeuilleMichaud, Université Clermont I, Pathogénie Bactérienne Intestinale, Clermont-Ferrand, France. Bacteria were grown routinely in Luria-Bertani (LB) broth or on LB agar plates overnight at $37^{\circ} \mathrm{C}$.

\section{Cell culture and infection protocol}

The human colorectal cancer cell line Caco-2 was obtained from the American Type Culture Collection (ATCC, Manassas, VA, USA). Cells were cultured in Dulbecco's modified Eagle medium (DMEM) with Lglutamine supplemented with $10 \%$ heat-inactivated fetal calf serum (Moregate, Hamilton, New Zealand), $1 \mathrm{mM}$ sodium pyruvate and $1 \mathrm{mM}$ non essential amino acids. All reagents were supplied from Invitrogen, Auckland, New Zealand. Cultures were maintained at $37^{\circ} \mathrm{C}$ in a humidified $5 \% \mathrm{CO}_{2}$ atmosphere. Monolayers were seeded in 24well tissue culture plates (BD, Bioscience, Auckland, New Zealand) with $2 \times 10^{5}$ cells/well and incubated for 14 days. During this time the cell medium was constantly replenished.

For infection experiments, bacteria were grown overnight in LB broth at $37^{\circ} \mathrm{C}$. Before starting the infection the cell monolayers were washed twice with phosphate-buffered 


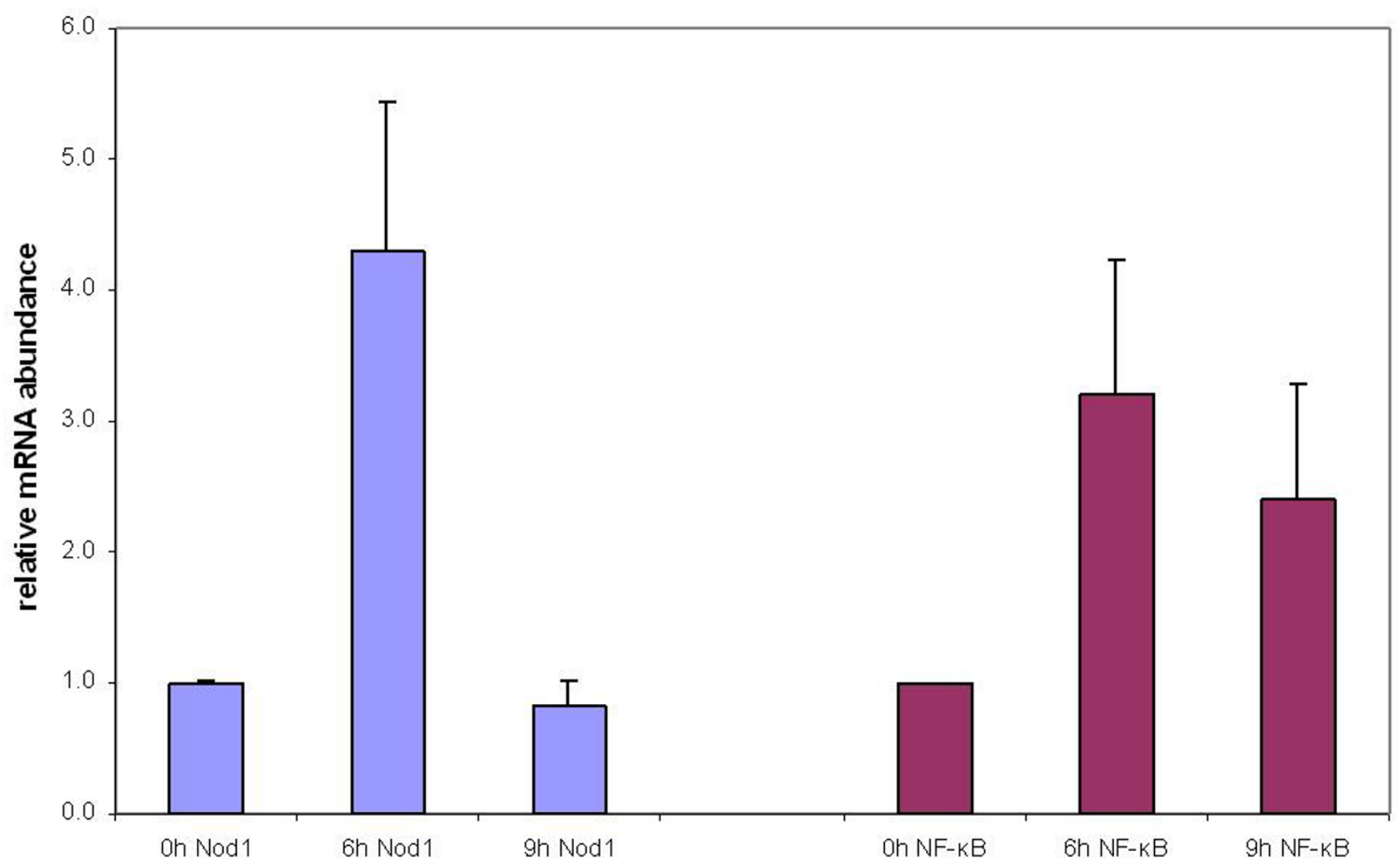

Figure I

Infection with E. coli LF82 alters m RNA levels for Nod I and NF- $\kappa$ B. Total RNA was isolated and cDNA synthesized by reverse transcription. NodI and NF- $\kappa B$ mRNA levels were assayed by real-time quantitative PCR using specific primers for these genes. cDNA levels were normalized using primers for Actin. Quantitative real time PCR reactions were performed in triplicate, and means and standard error plotted.

saline (PBS, pH 7.2). Each monolayer was infected in $1 \mathrm{ml}$ of the cell culture medium without FCS at a multiplicity of infection (MOI) of 10 bacteria per epithelial cell. After a 6 -h and 9-h incubation period at $37^{\circ} \mathrm{C}$ with $10 \% \mathrm{CO}_{2}$, infected monolayers were washed three times with PBS and the cells were trypsinated with 10\% Trypsin-EDTA (Invitrogen, Auckland, New Zealand). To remove the trypsin cells were centrifuged for $1 \mathrm{~min}$ at $1500 \mathrm{rpm}$ and the cell pellets were stored at $-80^{\circ} \mathrm{C}$.

\section{RNA isolation and RT-PCR}

Total RNA was extracted from non-infected and infected Caco2 cells using the RNeasy Mini Kit (Qiagen, Hilden, Germany) following manufacturer's protocols. The RNA

Table 6: Primer and probe sequences for custom made Sequenom SNP genotyping assay for NODI

\begin{tabular}{|c|c|c|}
\hline Primer & SNP_ID & Probe Sequences \\
\hline \multirow[t]{3}{*}{ Forward primer } & rs2075818 & ACGTTGGATGCACTCACATCCGCAATACTC \\
\hline & rs2075822 & ACGTTGGATGAAGGGGAGCAACAGGTGGGC \\
\hline & rs2907748 & ACGTTGGATGAGGGTGGGCTCCTCTACAG \\
\hline \multirow[t]{3}{*}{ Reverse primer } & rs2075818 & ACGTTGGATGGGCAGGCACACACAATCTCC \\
\hline & rs2075822 & ACGTTGGATGAAGGGCCATGGTCATGAGTC \\
\hline & rs2907748 & ACGTTGGATGACAGAAGGTCAATGGGACTC \\
\hline \multirow[t]{3}{*}{ Extend primer } & rs2075818 & TAAGAATGACTACTTCTCGGC \\
\hline & rs2075822 & GGGCATCGGGAATGGCA \\
\hline & rs2907748 & GTGGGCTCCTCTACAGGTAGCT \\
\hline
\end{tabular}


was quantified spectrophotometrically and then stored at $-80^{\circ} \mathrm{C}$. Reverse transcription of $1.5 \mu \mathrm{g}$ of total RNA to complementary DNA (cDNA) was carried out using the SuperScript ${ }^{\mathrm{TM}}$ III First-strand Synthesis - Super Mix Kit (Invitrogen, Auckland, New Zealand) and oligo(dT) ${ }_{20}$ primers, according to the standard protocol. The primers used for PCR had the following sequences: NF- $\kappa B, 5$ 'ACAAATGGGCTACACCGAAG-3', 5'-GGACAACGCAGTGGAATTTT-3'; Nod1, 5'-AGCTGAAGATGAATTTGG G AAA 3', 5'-GCCGAGAAGTAGTCATTCTTCAG-3' and Actin 5'-CATTGCCGACAGGATGCA-3', 5'-CCGATCCACACGGAGTACTTG-3'. These sets of primers yield to PCR products that were $198 \mathrm{bp}(\mathrm{Nod} 1), 341 \mathrm{bp}(\mathrm{NF}-\kappa \mathrm{B})$ and 102 bp (Actin) long, respectively. Results are expressed as the relative mRNA accumulation corrected using Actin mRNA as an internal standard.

\section{Statistical analysis}

The allelic trend test [25] and Fisher's exact genotypic test were used to compare case and control allele frequencies. An exact test was used to test for departures from HardyWeinberg equilibrium (HWE) in the case and the control samples [26]. Allelic odds ratios were calculated and confidence intervals for the allelic odds ratio were also calculated under the assumption of HWE in the cases and the control groups. Logistic regression analysis was used for subgroup analysis. Other analyses were carried out using R [27], SHEsis [28] (available from http://analysis.biox.cn/myAnalysis.php), and SAS (V9.1 SAS Institute., Cary, NC, USA).

\section{Abbreviations}

CARD: caspase-activated recruitment domain; CD: Crohn's disease; IC: Indeterminate colitis; NOD: nucleotide oligomerisation domain; OR: Odds ratio; PRRs: pattern recognition receptors; SNP: Single Nucleotide Polymorphism; UC: ulcerative colitis.

\section{Competing interests}

The authors declare that they have no competing interests.

\section{Authors' contributions}

$\mathrm{CH}$ helped with the genetic analyses and performed the functional analyses on NOD1. LRF managed the study and drafted the manuscript. DYH and BLB carried out the statistical analyses. MP helped design the primers for the genotyping experiments. MLB and RLG recruited participants and participated in the design of the database. AMC and PSB coordinated the database. All authors read and approved the final manuscript.

\section{Acknowledgements}

We thank Rebecca Roberts for help preparing the DNA plates, Ivonne Petermann for help with designing the primers, and the Canterbury participants in our study. Other funding sources for the case and control DNA collection are the Canterbury Medical Research Foundation and Canter- bury Liver and Digestive Diseases Trust. Nutrigenomics New Zealand is a collaboration between AgResearch Ltd., Crop \& Food Research, HortResearch and The University of Auckland, with funding through the Foundation for Research Science and Technology.

\section{References}

I. Hruz P, Eckmann L: Caspase recruitment domain-containing sensors and adaptors in intestinal innate immunity. Curr 2008, 24(2): $108-1 \mid 4$.

2. Ogura Y, Bonen DK, Inohara N, Nicolae DL, Chen FF, Ramos R, Britton $\mathrm{H}$, Moran T, Karaliuskas R, Duerr RH, et al:: A frameshift mutation in NOD2 associated with susceptibility to Crohn's disease. [see comment]. Nature 200 I, 4 I I (6837):603-606.

3. Hugot JP, Chamaillard M, Zouali H, Lesage S, Cezard JP, Belaiche J, Almer S, Tysk C, O'Morain CA, Gassull M, et al.: Association of NOD2 leucine-rich repeat variants with susceptibility to Crohn's disease. [see comment]. Nature 200I, 4 I I (6837):599-603.

4. Barrett JC, Hansoul S, Nicolae DL, Cho JH, Duerr RH, Rioux JD, Brant SR, Silverberg MS, Taylor KD, Barmada MM, et al.: Genomewide association defines more than $\mathbf{3 0}$ distinct susceptibility loci for Crohn's disease. Nat Genet 2008, 40(8):955-962.

5. Zouali H, Lesage S, Merlin F, Cezard JP, Colombel JF, Belaiche J, Almer S, Tysk C, O'Morain C, Gassull M, et al:: CARD4/NODI is not involved in inflammatory bowel disease. Gut 2003, 52(I):7I-74.

6. McGovern DP, Hysi P, Ahmad T, van Heel DA, Moffatt MF, Carey A, Cookson WO, Jewell DP: Association between a complex insertion/deletion polymorphism in NODI (CARD4) and susceptibility to inflammatory bowel disease. Hum Mol Genet 2005, I 4( I 0): I 245- I 250.

7. Canto E, Ricart E, Busquets D, Monfort D, Garcia-Planella E, Gonzalez D, Balanzo J, Rodriguez-Sanchez JL, Vidal S: Influence of a nucleotide oligomerization domain I (NODI) polymorphism and NOD2 mutant alleles on Crohn's disease phenotype. World J Gastroenterol 2007, I3(4I):5446-5453.

8. Franke A, Ruether A, Wedemeyer N, Karlsen TH, Nebel A, Schreiber $\mathrm{S}$ : No association between the functional CARD4 insertion/ deletion polymorphism and inflammatory bowel diseases in the German population. Gut 2006, 55(I I): I679- I680.

9. Tremelling $M$, Hancock L, Bredin F, Sharpstone D, Bingham SA, Parkes $M$ : Complex insertion/deletion polymorphism in NODI (CARD4) is not associated with inflammatory bowel disease susceptibility in East Anglia panel. Inflamm Bowel Dis 2006, I 2(I 0):967-97I.

10. Van Limbergen J, Nimmo ER, Russell RK, Drummond HE, Smith L, Anderson NH, Davies G, Arnott ID, Wilson DC, Satsangi J: Investigation of NODI/CARD4 variation in inflammatory bowel disease using a haplotype-tagging strategy. Hum Mol Genet 2007, I 6( I 8):2175-2186.

II. Gearry RB, Roberts RL, Burt MJ, Frampton CM, Chapman BA, Collett JA, Shirley P, Allington MD, Kennedy MA, Barclay ML: Effect of inflammatory bowel disease classification changes on NOD2 genotype-phenotype associations in a population-based cohort. Inflamm Bowel Dis 2007, I3( I 0): I220-I227.

12. Browning BL, Huebner C, Petermann I, Demmers P, McCulloch A, Gearry RB, Barclay ML, Shelling AN, Ferguson LR: Association of DLG5 variants with inflammatory bowel disease in the New Zealand Caucasian population and meta-analysis of the DLG5 R30Q variant. Inflamm Bowel Dis 2007, I3(9): I069-1076.

13. Browning BL, Huebner C, Petermann I, Gearry RB, Barclay ML, Shelling $A N$, Ferguson LR: Has toll-like receptor 4 been prematurely dismissed as an inflammatory bowel disease gene? Association study combined with meta-analysis shows strong evidence for association. Am J Gastroenterol 2007, I 02(I I):2504-25 I 2 .

14. Boudeau J, Glasser AL, Masseret E, Joly B, Darfeuille-Michaud A: Invasive ability of an Escherichia coli strain isolated from the ileal mucosa of a patient with Crohn's disease. Infect Immun 1999, 67(9):4499-4509.

15. Ozen SC, Dagli U, Kilic MY, Toruner M, Celik Y, Ozkan M, Soykan I, Cetinkaya H, Ulker A, Ozden A, et al.: NOD2/CARD I5, NODII CARD4, and ICAM-I gene polymorphisms in Turkish patients with inflammatory bowel disease. J Gastroenterol 2006, 4 I (4):304-3 I0. 
16. Molnar T, Hofner P, Nagy F, Lakatos PL, Fischer S, Lakatos L, Kovacs A, Altorjay I, Papp M, Palatka K, et al:: NODI gene E266K polymorphism is associated with disease susceptibility but not with disease phenotype or NOD2/CARDI5 in Hungarian patients with Crohn's disease. Dig Liver Dis 2007, 39( I 2): 1064-1070.

17. Van Limbergen J, Russell RK, Nimmo ER, Torkvist L, Lees CW, Drummond HE, Smith L, Anderson NH, Gillett PM, McGrogan P, et al.: Contribution of the NODI/CARD4 insertion/deletion polymorphism +32656 to inflammatory bowel disease in Northern Europe. Inflamm Bowel Dis 2007, 13(7):882-889.

18. Hysi P, Kabesch M, Moffatt MF, Schedel M, Carr D, Zhang Y, Boardman B, von Mutius E, Weiland SK, Leupold W, et al:: NODI variation, immunoglobulin E and asthma. Hum Mol Genet 2005, I 4(7):935-941.

19. Darfeuille-Michaud A, Boudeau J, Bulois P, Neut C, Glasser AL, Barnich N, Bringer MA, Swidsinski A, Beaugerie L, Colombel JF: High prevalence of adherent-invasive Escherichia coli associated with ileal mucosa in Crohn's disease. Gastroenterology 2004, 127(2):4|2-42|.

20. Gearry RB, Richardson A, Frampton CM, Collett JA, Burt MJ, Chapman BA, Barclay ML: High incidence of Crohn's disease in Canterbury, New Zealand: results of an epidemiologic study. Inflamm Bowel Dis 2006, I 2(10):936-943.

21. Burt MJ, George PM, Upton JD, Collett JA, Frampton CM, Chapman TM, Walmsley TA, Chapman BA: The significance of haemochromatosis gene mutations in the general population: implications for screening. Gut 1998, 43(6):830-836.

22. Silverberg MS, Satsangi J, Ahmad T, Arnott ID, Bernstein CN, Brant SR, Caprilli R, Colombel JF, Gasche C, Geboes K, et al.: Toward an integrated clinical, molecular and serological classification of inflammatory bowel disease: Report of a Working Party of the 2005 Montreal World Congress of Gastroenterology. Can J Gastroenterol 2005, I 9(Suppl A):5-36.

23. Leushner J, Chiu NH: Automated mass spectrometry: a revolutionary technology for clinical diagnostics. Mol Diagn 2000, 5(4):34I-348.

24. Bray MS, Boerwinkle E, Doris PA: High-throughput multiplex SNP genotyping with MALDI-TOF mass spectrometry: practice, problems and promise. Hum Mutat 200I, 17(4):296-304.

25. Sasieni PD: From genotypes to genes: doubling the sample size. Biometrics 1997, 53(4): |253-1261.

26. Wigginton JE, Cutler DJ, Abecasis GR: $A$ note on exact tests of Hardy-Weinberg equilibrium. Am 」 Hum Genet 2005, 76(5):887-893.

27. Ihaka R, Gentleman R: R: A language for data analysis and graphics. Journal of Computational and Graphical Statistics 1996, 5(3):299-314.

28. Shi YY, He L: SHEsis, a powerful software platform for analyses of linkage disequilibrium, haplotype construction, and genetic association at polymorphism loci. Cell Res 2005, 15(2):97-98

Publish with Bio Med Central and every scientist can read your work free of charge

"BioMed Central will be the most significant development for disseminating the results of biomedical research in our lifetime. "

Sir Paul Nurse, Cancer Research UK

Your research papers will be:

- available free of charge to the entire biomedical community

- peer reviewed and published immediately upon acceptance

- cited in PubMed and archived on PubMed Central

- yours - you keep the copyright

Submit your manuscript here:

http://www.biomedcentral.com/info/publishing_adv.asp
BioMedcentral 